\title{
Physical-Chemical Evaluation of the Cassia grandis L. as Fortifying Egg Powder
}

\author{
Jhunior Abrahan Marcía Fuentes ${ }^{1}$, Ismael Montero Fernández ${ }^{2}$, Selvin Antonio Saravia Maldonado ${ }^{3}$, \\ Ingris Mary Varela Murillo ${ }^{1}$, Carlos Misael Silva Altamirano ${ }^{1}$, Flavio José Hernández Bonilla ${ }^{4}$, \\ Elvis Geovani Cruz Tejada ${ }^{5}$, Bryan Francisco Castro Dereck ${ }^{6}$, Héctor Zumbado Fernández ${ }^{7}$ \\ $\&$ Manuel de Jesús Alvarez $\mathrm{Gil}^{8}$ \\ ${ }^{1}$ Faculty of Technological Sciences, National University of Agriculture, Catacamas, Olancho, Honduras \\ ${ }^{2}$ Department of Organic and Inorganic Chemistry, Polytechnic School, University of Extremadura, Cáceres, \\ Spain \\ ${ }^{3}$ Faculty of Earth Sciences and Conservation, National University of Agriculture, Catacamas, Olancho, \\ Honduras \\ ${ }^{4}$ Faculty of Sciences, National University of Agriculture, Catacamas, Olancho, Honduras \\ ${ }^{5}$ College of Professionals in Agricultural Sciences of Honduras, Honduras \\ ${ }^{6}$ Institute of Agrarian and Environmental Sciences, Federal University of Mato Grosso, Sinop, Brazil \\ ${ }^{7}$ Faculty of Health Sciences, Technical University of Manabí, Ecuador \\ ${ }^{8}$ Institute of Pharmacy and Food, University of Havana, Cuba \\ Correspondence: Jhunior Abrahan Marcia Fuentes, Faculty of Technological Sciences, National University of \\ Agriculture, Road towards Dulce Nombre de Culmí, Km 215, Barrio El Espino, Catacamas, Olancho, Honduras. \\ E-mail: juniorabrahamm@yahoo.com
}

Received: April 6, 2020

doi:10.5539/jas.v12n8p277
Accepted: June 29, $2020 \quad$ Online Published: July 15, 2020

URL: https://doi.org/10.5539/jas.v12n8p277

\begin{abstract}
This research responds to a new strategy of foods nutritionally modified to improve the bioavailability and quantity of nutrients in the egg. Fortification with iron is one of the most common and the sources that exist to obtain it are varied. Carao (Cassia grandis) is such one of them due to its content of inorganic iron and possible use in the fortification of egg products. In Honduras there are no validated studies on the fortification of powdered egg with iron coming from carao $(C$. grandis $)$, and its incidence as a potential alternative to treat iron-deficiency anemia. For its achievement, an objective was set out to evaluate the phenotypic, physicochemical and sensory characteristics of carao (C. grandis) to determine its fortifying capacity in powdered egg. Fresh eggs from the poultry farm of the National University of Agriculture and carao (C. grandis) from the department of Choluteca, Honduras were used as raw material. It was determined that the phenotypic characterizations of the carao fruit (C. grandis) were distributed in $11.81 \%$ seeds, $9.45 \%$ pulp and $78.74 \%$ bark. It has a length of $55 \mathrm{~cm}$, a width of $36 \mathrm{~mm}$, a thickness of $30 \mathrm{~mm}$, contains 80 locules and 60 seeds, and the fruit has a mass of $254 \mathrm{~g}$. Fresh carao pulp contains $72 \%$ soluble solids, a pH of 5.51 and a viscosity of $200.66 \mathrm{cP}$. The same, when subjected to dehydration increases $13 \%$ of soluble solids, however, its pH-maintains stability.
\end{abstract}

Keyword: carao, sustentability, funtional food, nutraceutical

\section{Introduction}

According to the report of the World Food Program (WPF), the Food and Agriculture Organization (FAO) and the International Fund for Agricultural Development (IFAD), Honduras has one of the highest rates of malnutrition in Mesoamerica. The lack of iron should be considered within the essential nutrients that cause significant deficiencies, generating an incidence of iron-deficiency anemia, ranking first in rural populations (Fernández et al., 2017).

Nowadays, there are studies that validate the medicinal potential of carao (C. grandis) due to its phytochemical composition, antioxidant capacity and its high bioavailability and nutraceutical potential (Marcía et al., 2020). 
Different therapeutic properties have been attributed to it highlighting the treatment against anemia, the laxative effect, and the reduction of bleeding (Quirós, 2007; Lafourcade et al., 2018). The fruit of carao (C. grandis) has shown its antianemic potential from in vivo studies through its inorganic iron content and good bioavailability (Tillán et al., 2004; Lafourcade et al., 2014; Lafourcade et al., 2016).

The addition of nutrients to food, either by enriching (as a substitute of nutrients lost in the process) or by fortification (the addition of nutrients at levels higher than those occurring naturally in the food), improves the levels of one or more nutrients of certain foods for mass consumption, which increases the intake to more desirable levels (Durán et al., 2012).

Also, improves the nutritional chemical quality of some foods with a low amount of protein, lipids and minerals in their composition (Marcía et al., 2019).

According to Gil et al. (2016), we can define as functional food the one whose consumption contributes to provide health benefits above the strictly nutritional contribution, in addition, it presents compounds identified as physiologically active and with proven positive effects to maintain and improve health, as well as to prevent the emergence of certain diseases.

Powdered eggs are products with particular functional properties that, in some cases, are not found in liquid eggs, besides that, powdered yolks are less widespread since they are naturally rich in solids, so dehydration does not reduce their volume considerably. By contrast, powdered egg white is the main egg product on the international market, since it presents a greater reduction in its volume during dehydration, and additionally, its techno-functional properties increase during this process (Shimabukuro, 2017).

Therefore, this research aims to evaluate the physical-chemical characteristics of carao ( $C$. grandis) through laboratory analysis to determine its fortifying capacity in powdered eggs.

\section{Materials and Method}

\subsection{Sample Collection and Preparation}

The research was carried out at the Institute of Biotechnology of the National University of Agriculture, located in the department of Olancho, Honduras. For its achievement, fresh egg and carao fruit (Cassia grandis) was used as raw material. Their phenotypic, physical-chemical and sensory characteristics were evaluated and used for the development of four types of flour (egg, rind, seed and carao pulp flour respectively), taking full advantage of all the carao (Cassia grandis) fruit.

\subsection{Phenotypic Characterization of Carao (C. grandis L.)}

For phenotypic characterization, 100 units of the carao fruit were taken to measure their length, diameter and number of locules. The number of seeds and weight of the fruit were quantified and its mass distribution was determined using slight modifications of the methodology proposed by Velasco et al. (2010).

\subsection{Physicochemical Characterization of the Egg}

For this procedure, a total of 10 fresh eggs were randomly selected from a group of 100 units. Tests were performed and determined in triplicate of soluble solids, $\mathrm{pH}$, density and viscosity Quitral et al. (2009). Moreover, buoyancy tests were carried out to determine its freshness in accordance with the methodology described by the Egg Studies Institute (2009).

\subsection{Obtaining the Flours}

To obtain the flour from carao (C. grandis), samples of $1000 \mathrm{~g}$ of seeds and fresh pulp were taken and dehydrated for 75 hours at a temperature of $50{ }^{\circ} \mathrm{C}$ according to the methodology described by Pajarito Parker (2005). Later, it was pulverized in a mill and sieved, being stored until performing the analyzes. Then, to obtain the flour from the crusts, it was first cleaned with a solution of water and $\mathrm{NaCl}$ in a 9:1 ratio, dried at $50{ }^{\circ} \mathrm{C}$ and, subsequently mill-milled and sieved with a particle size of $212 \mu \mathrm{m}$, being stored at a room temperature until performing the analyzes.

Finally, to obtain the egg flours, a batch of 1000 units of eggs was started, being segmented into 10 groups of 100 units each. Each group of 100 units was homogenized using the methodology proposed by Sánchez et al. (2018) to obtain the egg flour.

\subsection{Physicochemical Characterization of Egg Meal}

For the physicochemical determinations, a solution of the 5 -gram flours in $50 \mathrm{~mL}$ of distilled water was prepared where the $\mathrm{pH}$, soluble solids, viscosity, water retention capacity and wettability were determined. For the wettability test, the method proposed by Sotelo and González (2000) was used, where $10 \mathrm{~g}$ of pulverized eggs 
were used being dissolved in $75 \mathrm{~mL}$ of distilled water, leaving them to stand until witnessing stability and absence of turbulence, controlling the time of wettability totally.

To determine the water retention capacity (CRA), $0.5 \mathrm{~g}$ of powdered egg was dissolved in a test tube with $3 \mathrm{ml}$ of water and then taken to a magnetic stirrer at $1000 \mathrm{rpm}$ for 1 minute, it was expected to precipitate for 12 hours, then it was decanted to extract the water that could not be retained and CRA was determined using the formula proposed by Zumbado, (2004).

\subsection{Obtaining the Optimized Formula}

To obtain the optimized formula, 18 experimental runs were used by means of block design (Table 1), with a $95 \%$ confidence interval. Sensory acceptance was taken as the response variable.

Table 1. Minimum and maximum values per component in the formulations

\begin{tabular}{lll}
\hline Component & Minimum value (\%) & Maximum value (\%) \\
\hline Egg powder & 20 & 80 \\
Carao pulp flour & 0.05 & 30 \\
Carao seed flour & 0.05 & 30 \\
Carao bark flour & 0.05 & 30 \\
\hline
\end{tabular}

The acceptability of the formulations was established from hedonic tests of 5 points on a laboratory scale, with 60 affective judges.

\section{Results and Discussion}

Table 2 shows the phenotypic parameters of carao (C. grandis).

Table 2. Phenotypic determination of carao (Cassia grandis)

\begin{tabular}{ll}
\hline Fruit characteristics & Dimensions \\
\hline Length & $55 \pm 1^{*} \mathrm{~cm}$ \\
Width & $36 \pm 1^{*} \mathrm{~mm}$ \\
Thickness & $30 \pm 1^{*} \mathrm{~mm}$ \\
Number of locules & $80 \pm 1^{*}$ units \\
Amount of seeds & $60 \pm 1^{*}$ units \\
Total weight of seeds & $30 \pm 1^{*} \mathrm{~g}$ \\
Pulp weight & $24 \pm 1^{*} \mathrm{~g}$ \\
Bark weight & $200 \pm 1^{*} \mathrm{~g}$ \\
Total weight of the fruit & $254 \pm 3^{*} \mathrm{~g}$ \\
\hline
\end{tabular}

Note. * Standard deviation values.

Table 3 shows the values of the physicochemical parameters for the carao ( $C$. grandis) pulp, both fresh and dehydrated, as well as in the pulverized seed.

Table 3. Physicochemical parameters for carao (C. grandis) fruit

\begin{tabular}{llll}
\hline Parameter & Fresh pulp & Dehydrated pulp & Powdered carao seed \\
\hline $\mathrm{pH}$ & $5.51 \pm 0.03$ & $5.50 \pm 0.01$ & $5.73 \pm 0.12$ \\
${ }^{\circ}$ Brix & $72.16 \pm 0.23$ & $85.02 \pm 0.02$ & $4.16 \pm 0.12$ \\
Viscosity (cP) & $200.66 \pm 0.47$ & - & - \\
\hline
\end{tabular}

The data were taken in triplicate with a t-student value of $95 \%$. The seeds analyzed have a moisture percentage of $8.19 \%$ and a particle size of $212 \mu \mathrm{m}$.

In Table 3, the first parameter evaluated was $\mathrm{pH}$, where it can be seen that the pulp retains both fresh and dehydrated acidity. Such acidity increased slightly for the seed, in contrast to ${ }^{\circ}$ Brix, where it is very small 
compared to the pulp. These results coincide with those expressed by Quirós (2007) and Gonzáles (1987); indicating that the carao pulp contains a $\mathrm{pH}$ of 5.3 and a soluble solids content of $73.5 \%$. The carao $(C$. grandis) fruit has less acidity than other tropical fruits such as Pouteria caimito or Psidium catteianum that present lower values than those found in this work, without reaching pH values of 5.00 (Montero et al., 2020).

Table 4 presents the physicochemical analyzes of raw and powdered eggs.

Table 4. Physicochemical evaluation of the egg $\left(25^{\circ} \mathrm{C}\right)$

\begin{tabular}{lllllll}
\hline Sample & Density $\left(\mathrm{kg} \mathrm{m}^{3}\right)$ & Minerals (\%) & Soluble Solids (\%) & $\mathrm{pH}$ & Viscosity (cP) & Humidity (\%) \\
\hline Fresh Egg & 1041 & 22 & 29 & 8.4 & 1027 & 71 \\
Egg powder & - & - & 81 & 9.6 & 2200 & 13 \\
\hline
\end{tabular}

When comparing the physicochemical parameters of powdered and dehydrated egg, we observe that both the amount of soluble solids and the $\mathrm{pH}$ increase when it is dehydrated. This product has a high nutritional value at low cost, with nutritional importance at an industrial level given these functional properties (Pleti et al., 2009). The percentage of minerals determined in Table 4 is $22 \%$, with the main components of this mineralogical percentage being iron, phosphorous, zinc and selenium (NECTA, 2005).

Another of the parameters determined in the egg powder samples was the water retention capacity, due to its high hygroscopicity of 18 experimental formulations and their response regarding acceptability to determine the optimized formulation. A chromatic system was used in the bar graph for its best interpretation, with the green color representing the greatest acceptability and the red being the highest rejection. The results of the test indicate that formulation number 5 is the optimized one, obtaining in 52 judges the rating. This formula consists of the mixture of $80 \%$ dried egg powder, $19.90 \%$ dried carao pulp, $0.05 \%$ dried carao seed, $0.05 \%$ dried carao powder (Figure 1).

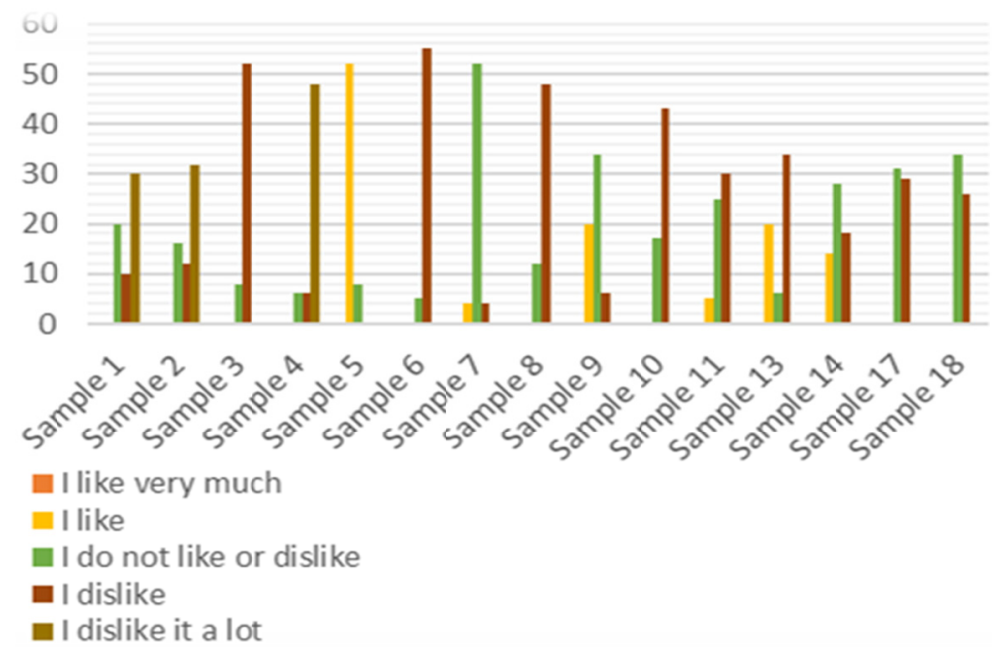

Figure 1. Acceptability of hedonic scale formulations

\section{Conclusions}

From phenotypic characterizations, the carao (Cassia grandis) fruit was determined to be distributed in $11.81 \%$ seeds, $9.45 \%$ of pulp and $78.74 \%$ of bark. It is $55 \mathrm{~cm}$ long, $36 \mathrm{~mm}$ wide, $30 \mathrm{~mm}$ thick, contains 80 locules and 60 seeds, and the fruit has a mass of $254 \mathrm{~g}$.

The fresh carao (Cassia grandis) pulp contains $72 \%$ soluble solids, a pH of 5.51 and a viscosity of $200.66 \mathrm{cP}$. The same when subjected to dehydration increases $13 \%$ of soluble solids, however, its $\mathrm{pH}$ maintains stability.

The appropriate temperature for dehydration of carao (Cassia grandis) seeds is $50{ }^{\circ} \mathrm{C}$ for 75 hours and for dehydration of the egg $54 \pm 10^{\circ} \mathrm{C}$ was used for $4 \mathrm{~h}$. 
The powdered egg presented high water retention capacity and low solubility, which shows its high hygroscopicity. The formula optimized for its greater acceptability is the mixture of $80 \%$ powdered egg, $19.9 \%$ dehydrated pulp and seeds, and $0.05 \%$ powdered carao bark, respectively.

\section{Acknowledgements}

To the College of Professionals in Agricultural Sciences of Honduras, COLPROCAH.

\section{References}

Díaz, T. R. (2009). Food preservation (p. 356). Felix Varela University Publishing House, Havana, Cuba.

Durán, S., Freixas, A., Saavedra, J., Maureira, R., Berrios, D., \& Gaete, C (2012). Consumption of fortified foods in secondary students of the metropolitan region of Chile.

Egg Studies Institute. (2009) The Great Egg Book (p. 168). Retrieved from https://www.portalveterinaria.com/ avicultura/articulos/13232/el-huevo-como-alimento-funcional-y-suscomponentes.html

Escandell, C. J., \& Polo, V. J. (2016). Chemical Kinetics for Pharmacy and Food (p. 158). Felix Varela University Publishing House, Havana, Cuba.

Fernández, L. P., Ros, B. G., Barrientos, A. S., Elsa, J. E., \& Frontela, S. C. (2017). Contribution of bioavailable iron and zinc to the diet of Honduran children under 24 month. Nutrición Hospitalaria, 34(2), 290-300. https://doi.org/10.20960/nh.1161

Gil, P., Barroeta, A. C., \& Garcés, C. (2016). The egg as a functional food and its components. Veterinary Portal.

Lafourcade, P. A., Bitencourt, A., Rodríguez, A. J. R., Cruz, A. S. R., Tavares, C. J. C., \& Pinho, F. C. (2016). Development and characterization of Cassia grandis and Bixa orellana nanoformulations. Curr. Top. Med. Chem., 16, 1-9. https://doi.org/10.2174/1568026616666160215161103

Lafourcade, P. A., Rodríguez Amado, J., Escalona Arranz, J., \& Fuenzalida, C. (2014). State of the art on Cassia grandis L. f. (cañandonga). Cuban Journal of Medicinal Plants, 19(1), 21-28.

Lafourcade, P. A., Rodríguez, A. J., Keita, H., Zapata, E., Carvalho, H., Silva, L. E., \& Tavares, C. J. (2018). Cassia grandis fruit extract reduces the blood glucose level in alloxaninduced diabetic rats. Biomedicine \& Pharmacotherapy, 103, 421-428. https://doi.org/10.1016/j.biopha.2018.04.059

Marcía Fuentes, J. A., Montero Fernández, I., Zumbado, H., Lozano-Sánchez, J., Santos Alemán, R., Navarro-Alarcón, M., ... Saravia Maldonado, S. A. (2020). Quantification of Bioactive Molecules, Minerals and Bromatological Analysis in Carao (Cassia grandis). Journal of Agricultural Science, 4(1), 6-10. https://doi.org/10.5539/jas.v12n3p88

Marcía Fuentes, J., Chavarría Carrión, L., \& Zumbado, H. (2019). Analysis of the cassava flour process, on the sensory and nutritional properties of cassava (Professional Article). Nexo Revista Cientifica, 32(01), 88-93. https://doi.org/10.5377/nexo.v32i01.7992

Montero, I. F., Saravia, S. A. M., Santos, R. A., Marcia, J. A. F., Silva, S. M., \& Chagas, E. A. (2020). Use of Amazon Fruits Barks as Source of Nutrients. Journal of Agricultural Science, 12(3), 233-245. https://doi.org/10.5539/jas.v12n3p233

NECTA (Nucleus of Studies in Poultry Science and Technology). (2005). Retrieved from http//www.nucleoe studo.ufla.br

Pajarito Parker, J. L. (2005). Obtaining and characterizing organic whole quinoa flour (p. 45, Thesis, Department of Food Science and Chemical Technology, Faculty of Chemical and Pharmaceutical Sciences, University of Chile).

Pleti, A. K., Lima, J. J., \& Cândido, L. M. B. (2009). Qualidade interna do ovo de avestruz após estocagem em temperatura ambiente e refrigerada. Ciência Rural, Santa Maria, 39(6), 1864-1868. https://doi.org/10.1590/ S0103-84782009005000113

Prokopiuk, D. B. (2004). Coffee substitute from carob (Prosopis alba Griseb) (p. 107, PhD Thesis in Food Sciences, Polytechnic University of Valencia, Spain).

Quiróz, S. (2007). Study of the effect of the product Cassia grandis (Carao) on smooth muscle in different tissues in vivo and ex vivo (pp. 4-55, Postgraduate Thesis, Faculty of Biomedical Sciences, Magister Scientiae in Biochemistry, Ciudad Universitaria Rodrigo Facio, University of Costa Rica). 
Quitral, V., Donoso, M. L., \& Acevedo, N. (2009). Physicochemical and sensorial comparison of field, organic and commercial eggs. Revista de Salud Pública y Nutrición, 10(2),1-10.

Sánchez, O. R., Guerrell, J., Reyes, E., \& Quiroz, V. (2018). Obtaining, Physicochemical and Microbiological Characterization of Powdered Egg and Its Use in the Food Industry in the Republic of Panama (pp. 58-69). Food Technology Research Center, Regional University Center of Coclé, University of Panama.

Shimabukuro, K. (2017). Monographic Work: Techno-functional properties of egg products intended for export (p. 51). National Agrarian University, La Molina, Lima, Peru.

Sotelo, A., \& González, L. (2000). Powdered egg with low cholesterol content. Nutritional and health characteristics of the product (online). Latin American Nutrition Archives, 50(2), 134-141. Retrieved from http://ve.scielo.org/scielo.php?script=sci_arttext\&pid=S0004-06222000000200004

Tillán Capó, J., Rodríguez Chanfrau, J., Gómez Mirabal, J. M., Pardo Ruíz, Z., \& Agüero Fernández, S. (2004). Antianemic activity of Cassia grandis L. Cuban Journal of Pharmacy, 38(3), 1. Retrieved June 20, 2020, from http://scielo.sld.cu/scielo.php?script=sci_arttext\&pid=S0034-75152004000300009\&lng=es\&tlng=es

Velasco Zebadúa, M. E., Perezgrovas Garza, R. A., González Hernández, V., Hernández Garay, A., Salvador Figueroa, M., \& Martínez Tinajero, J. (2010). Ethnobotany, phenology, and pod production in Cassia grandis L. f. from the center of Chiapas. Rev. Fitotec. Mex., 33(4), 333-341.

Zumbado, H. (2004). Chemical analysis of food, classic methods (p. 435). Institute of Pharmacy and Food, University of Havana.

\section{Copyrights}

Copyright for this article is retained by the author(s), with first publication rights granted to the journal.

This is an open-access article distributed under the terms and conditions of the Creative Commons Attribution license (http://creativecommons.org/licenses/by/4.0/). 